\title{
Saranjana in Historical Record: The City's Invisibility in Pulau Laut, South Kalimantan
}

\author{
Mansyur \\ History Education Department, Lambung Mangkurat University, Indonesia \\ mansyur_daeng@yahoo.com
}

\begin{tabular}{ccc}
\hline Received & Accepted & Published \\
$25 / 12 / 2017$ & $23 / 01 / 2018$ & $30 / 04 / 2018$ \\
\hline
\end{tabular}

Abstract Saranjana is a mystical city that is a myth for the people of Pulau Laut, South Kalimantan. Rumours about this mysterious city became increasingly excited because its existence, but not recorded on the map of Indonesia. Therefore it is very interesting to examine from a historical point of view. The purpose of this paper is to uncover the historical side of the occult city suggestion on Pulau Laut. This study using the method of history is a method to test and analyze the critical records and relics of the past. The historical method consists of four stages, namely heuristics (data collection), source criticism, interpretation (interpreting facts) and historiography. The results show exist of Saranjana in a place between fact and myth. In conclusion, there are two hypotheses that the Saranjana is ethnic state Dayak Samihim tribe. Then the second hypothesis, that Saranjana is (only) the dream country of Prince Purabaya in the 18th century AD.

Keywords: saranjana; the city of mystery; occult; South Kalimantan.

\begin{abstract}
Abstrak Kota Saranjana adalah kota gaib yang mistosnya melegenda bagi masyarakat di wilayah Pulau Laut, Borneo/Kalimantan Selatan. Rumor soal kota misterius ini menjadi semakin heboh lantaran keberadaannya dianggap tidak tercatat dalam peta Indonesia. Oleh karenaitu sangat menarik diteliti dari sudut pandang historis. Tujuan penulisan ini untuk mengungkap sisi historis dari keberadaan kota gaib saranjada di Pulau Laut. Dalam penelitian ini menggunakan metode sejarah yakni metode untuk menguji dan menganalisa secara kritis rekaman dan peninggalan masa lampau. Metode sejarah terdiri dari empat tahap, yaitu heuristik (pengumpulan data), kritik sumber, interpretasi (menafsirkan fakta) dan historiografi. Hasil penelitian menunjukkan keberadaan Saranjana dalam posisi antara fakta dan mitos. Kesimpulannya terdapat dua hipotesa bahwa Saranjana adalah ethnic state Suku Dayak Samihim. Kemudian hipotesa kedua, bahwa Saranjana adalah (hanya) negeri impian Pangeran Purabaya pada Abad 18 Masehi.
\end{abstract}

Kata kunci : misteri; saranjana; kota gaib; Kalimantan Selatan. 


\section{INTRODUCTION}

Saranjana was already famous for the community of South Kalimantan. Rumours of this mysterious town problem becoming increasingly excited because of his existence, but not recorded in the map of Indonesia. Saranjana is a town of invisibility that cannot be seen by laymen, except with the inner eye. Communities in Kotabaru would have never heard the story of the mystical and occult, which is from generation to generation by word of mouth. About the place, diverse versions.

The first version only wrote that purportedly located in Kotabaru, South Kalimantan. On the second version sets forth that Saranjana is located in the Bay of Tamiang, Sea Island. The third version is more emphatically States that the location of the region of Saranjana is on a small hill in the village of Oka Oka-Marine Sea Island Subdistrict, South Kalimantan. The hills bordering the sea is beautiful and suitable tourist destinations. However, this place is considered haunted by the people around.

\section{METHOD}

This research uses historical method i.e. methods to test and analyze critically the recording and the relics of the past. Using the historical method, researchers trying to reconstruct as many of the events of the past. The use of this method is also simultaneously to test the credibility of sources as this report writing material. The historical method comprises four stages, i.e. heuristics, source criticism, interpretation and historiography.

\section{RESULT AND DISCUSSION}

\section{Saranjana Region: Between Facts and Myths}

How a historical perspective? The existence of Saranjana is a fact. Salomon Muller (1845), Germany naturalist who was born in Heidelberg, in the map titled Kaart van de Kust-en Binnenlanden van Banjermasing tot behoorende de zuidelijke Reize in het gedelte van Borneo (map of the coastal areas and inland Borneo), the year 1845 describes that there is the area that he wrote as Tandjong Serandjana. It is located south of Pulau Laut. Exactly Poeloe Kroempoetan (Kerumputan Island) adjoining the territory and Poeloe Kidjang (Kijang Island).

In his capacity as a cartographer, Salomon Muller served as a member of the des Genootschaps en Natuurkundige Komissie in Nederlands Indie already received training from the Leiden Museum and was doing research on the animal world travel and vegetation on the islands of Indonesia. Not yet ascertained whether Salomon Muller travelled to Tandjong Serandjana before mapping. Salomon Muller was not ever mentioned in a couple of articles published Verhandelingen van het Bataviaasch Genootschap van Kunsten en Arts. The map contains Tandjong Serandjana are loaded in Reizen en onderzoekingen in den Indischen Archipel, 
the first series published Staatsbibliothek zu Berlin. This map was made 18 years before Salomon Müller died in 1863.

Other sources containing about Serandjana is Pieter Johannes Veth in the Aardrijkskundig woordenboek van statistisch en Nederlandsch Indie: bewerkt naar de jongste en beste berigten in page 252. This dictionary was published in Amsterdam by P.N. van Kampen in 1869. Veth (1869) wrote down "Sarandjana, aan de kaap Oostzijde van Zuid-Poeloe sea, welk eiland aan Borneo's Zuid-Oost punt is gelegen" (Sarandjana, the southern side of Poeloe Laut, which is an island located in the southeastern part of Borneo). In terminology, if compared with the vocabulary of India, "Saranjana" means given land.

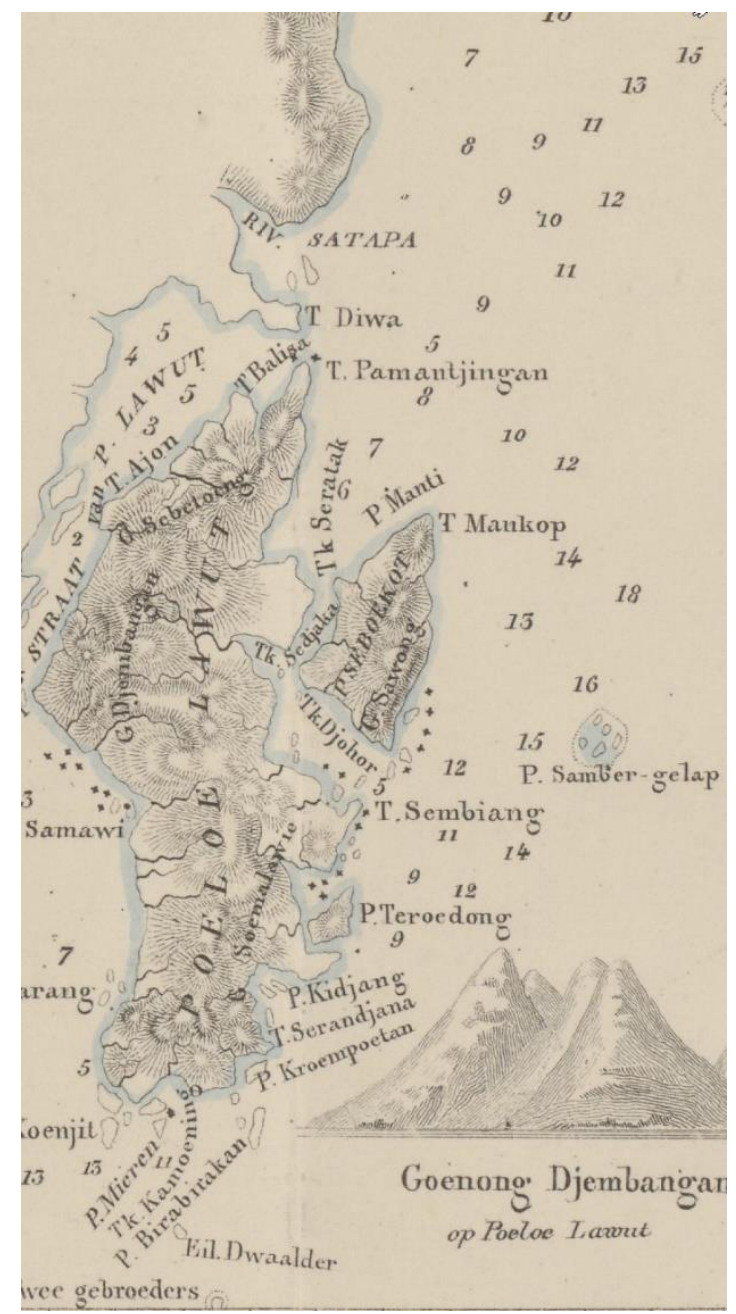

Picture 1. Solomon Muller Map, 1845. 


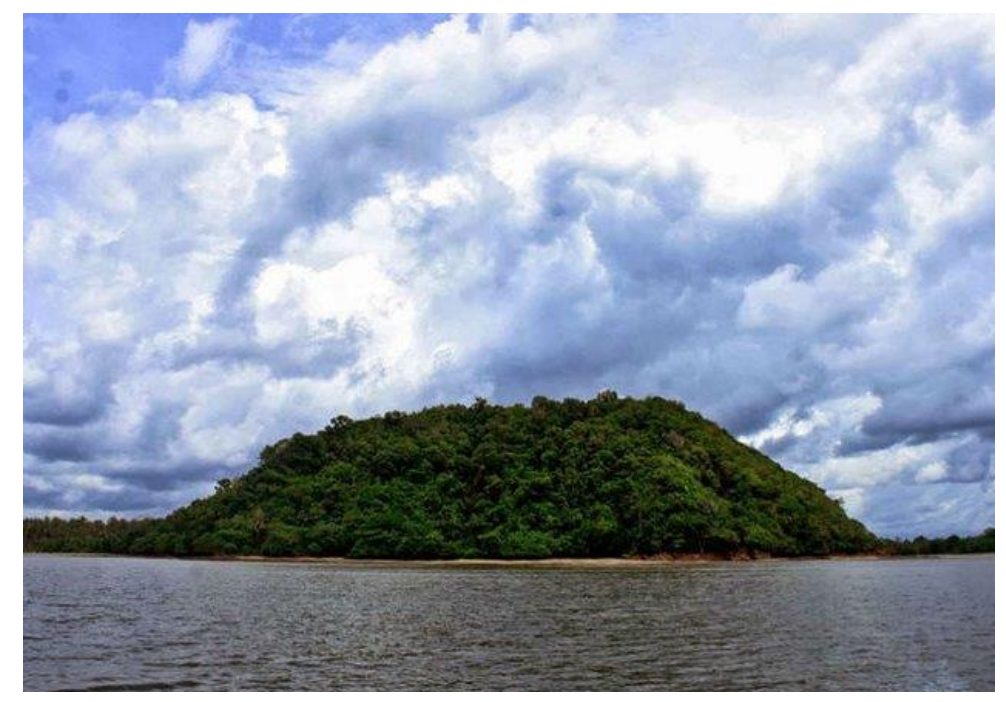

Picture 2. Saranjana Cape located in Pulau Laut

\section{From Saranjana to Sarangtiung: Reveals the Original Name of Saranjana}

Heard the name Saranjana, without the fear of a friend and then jokingly asked at once. First, what's the difference between Saranjana and Saranghaeyo, a popular Korean song since Eru? Second, if Saranjana dangdut song related Terajana popularized the "King of dangdut" Rhoma Irama? The answer, while a half-joking are: different! 사랑 in the language of Korea means love, while the meaning of 'terajana' is not so clear. Some are taken with ' how are you?

Scientifically, there is indeed a mental fact in the minds of the public supporting the belief of "the myth of the Saranjana" in Kotabaru. Bottom line, if there is a deliberately seek out areas of Saranjana, most of them will not be found. In addition to rows of facts from the Netherlands East Indies source described previously, there are indeed other sources. Sources certainly do not get left behind. To make the myth became real should be started from myths.

First thing, look at it from the point of view of language. The history of written language. The language became a symbol of the word. From this point of view, the existence of the name Saranjana/Sarangjana or Serandjana in the Netherlands naturalist writing, have in common with the toponym of Sarangtiung. The region of Saranjana in the South Sea Islands. While the Sarangtiung area in the northern part of the island of Corsica. Not an anomaly. Whether the elements of this similarity demonstrates the relationship? Need to be deepening. Sure thing, show where a "nest". Historical elements of proof in the context of lingua-historical will only be up there. The cause, minimal data. No sources indicating the existence of a relationship between the two areas. That is, this opinion only matching that has not been able to achieve adequate hypothesis.

The second thing is the terminology if compared with a vocabulary of India, "Saranjana" that means the given land. It is revealed by Indian Historian, Chaudhri (1919) in Indian Cases It is indeed quite far when looking for comparisons up to India. No one indeed. The fact India 
people wear this name. Call it the names of India, Saranjana Kulkarni. Company name Saranjana Manufacturing, and so on. However, this second opinion, again only became standard matching, because bump the data. Have never found relics of the "cultural manifestation" results of Indianization in Pulau Laut.

The search finally stopped in local oral sources. Normasunah (2017), in a publication titled Myths in Legend of Halimun Island Kingdom in Kotabaru Regency, giving another view. Local literary hanging from the "kulturalgebundenheid" or cultural community. The Legend of Halimun Island Kingdom. The central figures are the King of Pakurindang, Sambu Batung and Sambu Ranjana. She holds appropriate myths. Mount Saranjana is a reincarnation of the Halimun Island Kingdom. In the myth, King Pakurindang says, "Sambu Batung, you and the Putri Perak stay in the North of the island. Go on opening up and participating in real nature, and you Ranjana Sambu live in South to continue your ascetic. I bless that you guys did this path in life. But remember, even though living in different worlds, you guys should still get along well. Always help each other and alert". In conclusion, the name of which later Ranjana Sambu undergo "evolution" pronunciation became "Saranjana" in the local tongue.

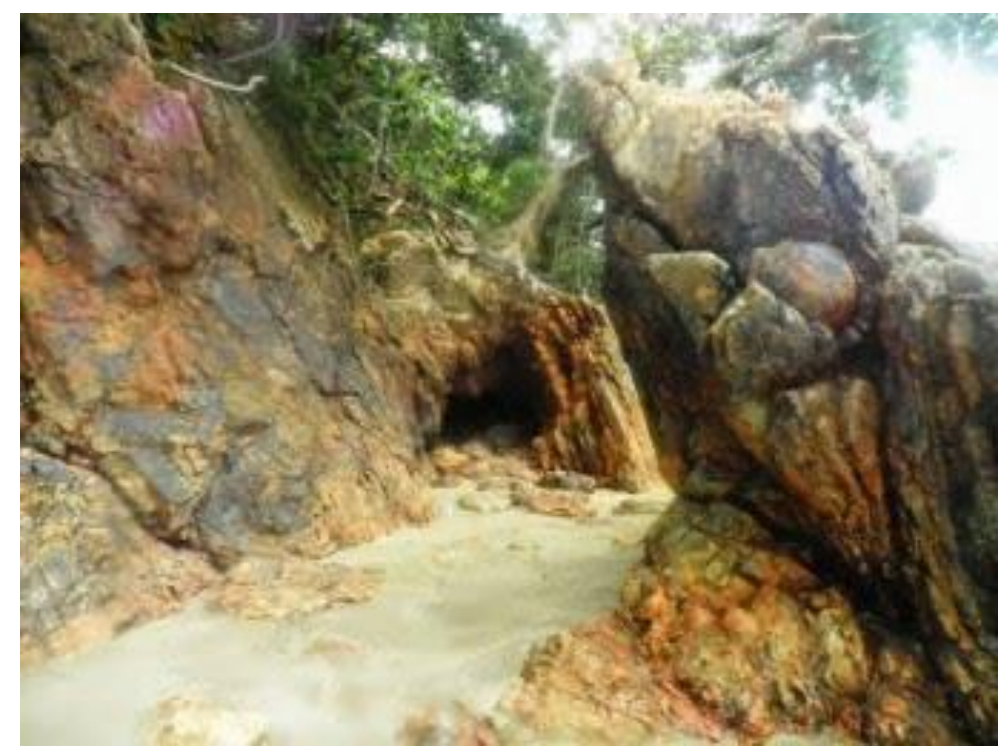

Gambar 3. The location of the cave is believed to be the public entrance to the Saranjana

Can this myth be trusted? How much the degree of truth? What about the historical element? Normasunah in his paper answers it. The myth is a part of the language that the substance lies not in style, rhythm or syntax, but on the story that disclosed. The function of myth lies in a special landscape in which the meanings of escape from a purely linguistic. The myth is language that is a structure that is actualized every time a particular story re-telling. Of opinion with historical perspective this lingua-at least not provide important information. The 
origin of the name Saranjana the most approaching truth is Sambu Ranjana. How the analysis of historical figures Sambu Ranjana and when the span of time?

\section{Saranjana, the Ethnic State of Dayak Tribe Samihim: An Early Hypothesis}

Like looking for a needle in a haystack. Such is the depiction of reality side efforts searching for the mythical area of Saranjana. The closer, the road is getting dark. The side of the occult, metaphysics that eventually many flourished in this realm. Nevertheless, the scientific side is not the depiction of things unseen. Extreme sentencing: "scientific research does not believe the things that are unseen".

Scientific research is based on the scientific method. Historical Method of History. One of the stages is interpretation. At this stage, it does generate many hypotheses (temporary conjecture). This is due to the lack of written data so that the main basis of researching Saranjana is based only on oral sources. Nevertheless methodologically, it can still reach it. In a sense, with the historical method, keep trying to reveal the existence of Saranjana although only until the alleged level is temporary. Of course, new data might be able to change it.

Tracing the existence of the Saranjana region in a scientific perspective raises some provisional conjecture. Next, it can increase its status to theory. The first hypothesis, that the Saranjana is the territory of the Dayak tribe who settled on Pulau Laut. Dayak tribe with seminomadic life. Dayak tribe in question is Dayak Samihim sub-ethnic Dayak tribe who inhabit the northeastern region of South Kalimantan. Radam (2001) believes the Samihim Dayak people are thought to include the Maanyan clump. Alleged separated sub-Maanyan tribe to Pulau Laut, due to the conquest of the surrounding areas when the establishment of the kingdom of Dipa State. In an oral source, singing or wadian Maanyan, their kingdom known as Nan Sarunai was damaged by Javanese forces called from Marajampahit or Majapahit.

Most probably Empu Jatmika ordered his commander, Arya Megatsari and Tumenggung Tatah Jiwa with his troops conquering Maanyan people who did not want to be the people of the Kingdom of the State of Dipa. Some groups of Maanyan people are expelled. Then they do the delivery to various corners in Kalimantan. Including the Dayak Samihim people who settled in the area Pamukan, Cengal, Manunggul, Bangkalaan to Pulau Laut which will become part of the Land of Tanah Bumbu. Another opinion as written in the book History Kotabaru that prior to the entry of Islam, Kotabaru populated inhabitants of the Dayak tribe who embraced the belief in Animism. Both in Kotabaru (Pulau Laut), Cengal, Cantung, Sampanahan and others still live in groups.

When is the time of existence of the estimated Saranjana region of the Dayak Samihim Tribe? Allegedly before the 1660 s AD. In other words before the 17th century. The reason, in the 
year 1660 based on the record Goh Yoon Fong, Pulau Laut has become a land apanage Prince Purabaya from the Sultanate of Banjar. Fong (1969) writes:

"Banjar nobility decided that Raden Bagus was appointed as Sultan of Banjar with the title of Sultan Amarullah Bagus Kusuma (1660-1663). And as a tribute and reward of peace, Prince Purabaya was awarded Pulau Laut area as his apanage land".

Saranjana early day is an ethnic state or tribal state. This is in line with Kulke's Theory (1986) which divides the formation of the country in Southeast Asia into three phases, namely tribal state, early state, and royal state. Suggestions in the form of the Ethnic State government in the first phase. Ethnic State is "dead" without having had a time of transition. The reason for this classification, because in an effort to express and explain the Saranjana highly relies on the traditional historiography of the legendary Halimun Island empire.

Traditional historiography has prominent and interrelated features, namely: (1) ethnocentrism, (2) king of centrism, (3) anthropocentrism. Similarly, in tracking the background of the existence of the Saranjana is still very dependent on the folklore shaped legend of this hereditary. Information obtained from the story of Halimun Island Legend is marked by mystical, legendary, and no chronological elements of time in the sequence of the story.

According to Kulke (1986), in Vida, the ethnic or ethnic state is made up of only one ethnic and its order is governed by a tradition transformed from ancestry to the next. The existence of the Saranjana is not supported by adequate written sources. The position of the chief was already known in the Saranjana society at that time. In this case, when relying on the oral source of the Legend of Halimun Island, as head of a tribe is a character named Sambu Ranjana.

As an Ethnic state, the Kingdom of Saranjana certainly has no regulation or bureaucracy as the kingdom is in the early state and state of the kingdom. Quoting the opinion of Vida Kusmartono who photographed the Kingdom of Nan Sarunai with the same theory that is Theory of Kulke, state or ethnic state kingdom is not tyrannical for who ordered. The Saranjana Society is a homogeneous society. They organize their community life in great harmony in accordance with customary rules containing traditional laws, including restrictions on customary law. The fundamental relationships within the Kingdom are created by genealogical or kinship relationships.

In its development, the life of the tribal supporters of the "Tribal Country" Saranjana lasted for centuries. The prevailing government still runs simply. They set up temporary shelters before moving to another location as described by H. Ling Roth in the mid-19th century. The areas that belong to the Saranjana Kingdom include the southern Halimun Island (Pulau Laut). With the status of the Tribal Kingdom, the Kingdom of Saranjana was never recorded to expand or expand the territory, either by war or by the claim of territory. 


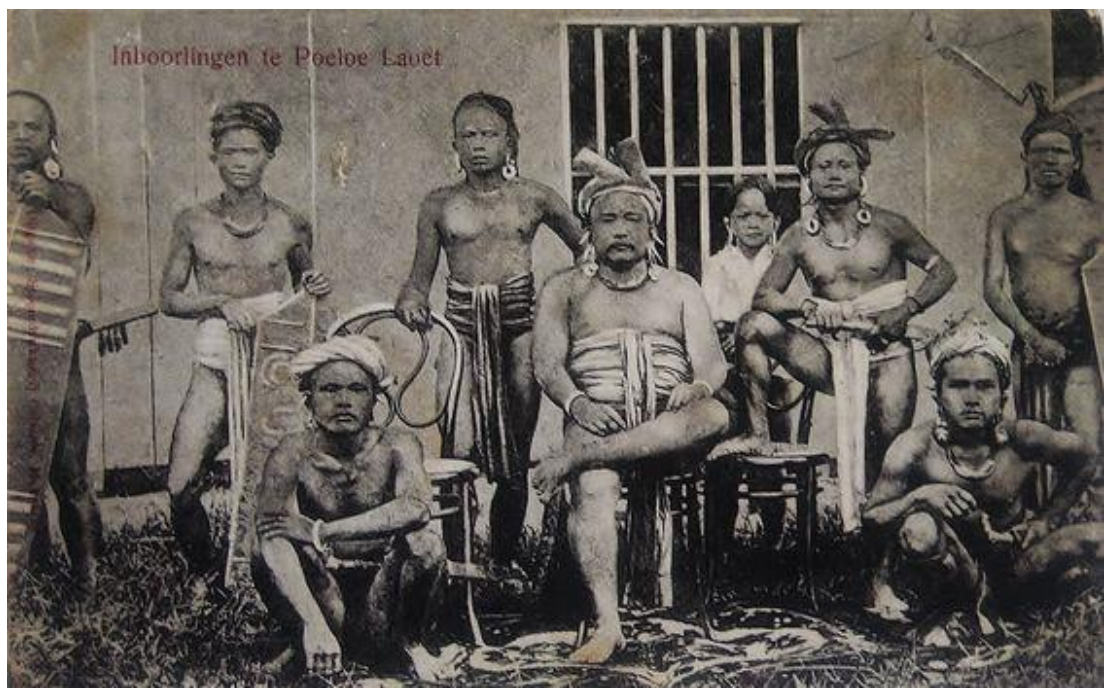

Picture 4. Photo of the Dayak Chief of the Pulau Laut, 1900s.

In its development, the head of Dayak tribe Samihim in the area of "ethnic state" Saranjana, most likely Sambu Ranjana figures have begun to get the influence of old Hindu elements. In accordance with the opinion of Faisal Batennie. He revealed the religion that first developed on the Sea Island is a Hindu religion. In addition, this can be viewed from the aspects of language, linguistic-related names. The name "Sambu" (Shambu) is inseparable from the Hindu belief. For example in Reg Veda, Sambu name is part of 11 rudra or prana rudra. Sambu has the meaning of meeting or joining. Another version of Sambu means strong, courageous, and wise. While the meaning of the word "Ranjana" in Kawi is joyful.

Regarding the move of the Dayak Samihim tribe from the location of the Saranjana Kingdom, it can be attributed to Schwaner's writing: "Historische, Geograpische en Statistieke Aanteekeningen Betreffende Tanah Boemboe", 1851. It is not yet certain whether Schwaner's writings depict the Kingdom of Saranjana or not. According to Schwaner, "the oldest stories circulate until the natives of that place called the Dayaks become rich and powerful, and live in villages surrounded by vast and beautiful gardens, under their kings and his descendants (Schwaner, 1851)

The history of the kingdom is mixed with stories of occult events, legendary acts and barbarian customs and ends with the destruction of the region by war with foreign powers that come with boats, attacking the population and destroying its territory. Thousands of people were killed and the rest were repulsed until the high mountains, where due to the pressures they have now become frightened and hid, living in several families and scattered in small villages. "

Conclusion, based on this hypothesis that the Saranjana Kingdom emerged before the 1660s or pre-17th century AD. Ethnic State Royal Sect of the Samakim Dayak Tribe. The first 
Tribe Head is Sambu Ranjana. Originally embracing animist beliefs. But as it progressed, it began to get along Hindu influence. This is evidenced by the name Sambu Ranjana that is influenced by Hindu elements. The nomadic Dayak tribe had a glorious experience. In the end, the Dayak Samihim tribe left the Saranjana area due to war with foreign powers that came with the boat, attacked the population and destroyed its territory. Despite leaving its territory, the name of the Samakim Dayak power centre in Pulau Laut is still called Saranjana.

\section{From Banjar to Saranjana: Between the Prahara and the Dreamland of Purabaya}

The "historical fact" searching process of this Saranjana eventually led to a long discussion. Especially the search process and get a conclusion. As a scientific comparison in the methodological framework, history became an option (Thompson, 2012; Vansina, 2014). Of course from the historical side trying to dig with the approach of social science and language. This paper ultimately boils down to a colonial source such as The Governor's letter of Macassar to Batavia, 24 November 1717. Then the phenomenal thesis of Goh Yoon Fong, Trade and Politics in Bandjarmasin 1700-1747 which reveals a hidden historical event on Pulau Laut. Goh Yon Fong is also a mysterious figure because of the existence of the author after writing his thesis in London, cannot be obtained. But apart from the mystery of Goh Yon Fong, at least the events he wrote, could be part of the hypothesis about Saranjana

Goh Yon Fong writes, when Raden Bagus (Sultan Amarullah Bagus Kusuma) in 16601663, ascended the throne of the Kingdom of Banjar, caused tempest. Behind his position as Sultan, caused some disappointment. The corner is revenge. The cause is no other ambition and the throne of Sultan Banjar. One of them is Prince Purabaya. Raden Bagus ascended the throne in place of the Sultan of the People of Allah (Prince Tapesana or Dipati Halit). Raden Bagus considered Gooh Yon Fong is entitled because he is the son of Sultan Saidullah (1637-1642). Selection of the Sultan has been established the nobility council of the Sultanate of Banjar.

On the other hand, Prince Purabaya also feels entitled to the throne because Prince Purabaya is the son of the sultan with his concubine from the daughter of Makasar. Prince Purabaya deliberately raised his name politically as the Crown Prince. The originator is Prince Dipati Halit or Prince Tapesana alias Sultan Rakyat Allah (1642-1660) ahead of the election of the Sultan who succeeded him. The early tempest occurred in the aristocracy of the Banjar Sultanate at the Kayutangi-Karang Intan palace by 1660.

Prince Dipati Anom with Queen Mother (from Biaju class) assisted by Sutadjaya and Panjangjiwa strongly supports his nephew Raden Bagus as Crown Prince appointed as Sultan. Finally, the conspiracy of Banjar royalty decided that Raden Bagus was appointed as Sultan of Banjar with the title of Sultan Amarullah Bagus Kusuma (1660-1663). Then as a tribute and reward of peace Prince Purabaya given Pulau Laut area as his apanage land. 
Sultan Amarulah Bagus Kusuma (1660-1663) ascended the throne as the Sultan of Banjar not only received the support of his uncle Pangeran Dipati Anom, as well as his grandmother Queen Mother, as well as the nobility of the Bubuhan Raja Banjar. Support also came from Portugal in Macao. Previously he had asked for Dutch assistance, but the Dutch refused. No doubt, a pepper monopoly was given to the Portuguese. When the Sultan ascended the throne, Portuguese ships abounded with pepper over special treatment as a reward from Sultan Amarullah Bagus Kusuma. Sultan Amarullah Kusuma's (1660-1663) or Raden Bagus's policy, as a step of peace to give Pulau Laut area to Prince Purabaya. Naturally, because at that time felt disappointed and resentment to the family of Sultan Amarullah Bagus Kusuma.

Sultan Amarullah Bagus Kusuma ascended the first throne (1660-1663) (then managed to reclaim the second throne from the reign of Sultan Surianata (1663-1679), Sultan Amarullah Bagus Kusuma continued the Sultanate of Banjar from 1680-1700.In both phases, it was revenge Pangeran Purabaya has not receded and arranged the strength at Pulau Laut as the base area of his struggle. When the giving of Pulau Laut Island as peace by the Sultan circa 1660 before, with full of disappointment and resentment, Prince Purabaya moved and arranged strength in the area of Pulau Laut. Geographically, Pulau Laut is opposite to Pamukan, Sampanahan, Cengal and surrounding areas only separated by a nearby strait. This had become the material of thought Sultan Amarullah Bagus Kusuma. Need to secure as early as the possible Pamukan area surrounding from occupation or chaos made by Prince Purabaya with his group.

In the period that is not much different, their rebellion from the Biaju people in 1711. This rebellion can be broken by the military forces led by the Prince of Purba Banjar. He was supported by a firearm of twenty ancient rifles. Suria Alam forgave the prisoners of the Biaju people by hoping that they would not make any more noise. But it's not that simple. Apparently, the Biaju people still grudge and join the Prince Purabaya in Pulau Laut. The people of Biaju begged the support of Prince Purabaya, owner of apanage Pulau Laut since 1660. When twice the reign of Sultan Amarullah Bagus Kusuma 1660-1663 and 1680-1700 Prince Purabaya with his group showed no visible action. However, when the reign of the king of Banjar afterwards, the rebellion took place. Former Biaju prisoners released by the sultan then appealed to Prince Purabaya on Pulau Laut to join against the royal apparatus of Banjar.

In addition to recruiting his troops from the Makasar people in coalition with the Biaju people, Pengeran Purabaya also sought additional support from Daeng Mamantuli, a Bugis prince who was expelled from Makasar because of his bad deeds. At that time Daeng Mamantuli was in Kutai as a guest of Kraing Bonteramboe (Karaeng Bontorambe) in order to support the claim of Kraing Bonteramboe on Sand area. In 1713 the troops of Prince Purabaya and his son Gusti Busu, Biaju troops and Daeng Mamantuli troops attacked Banjar, Hulu Barito, pepperproducing regions such as the State and Bakumpai were isolated. 
Sultan Suria Alam (Sultan Hamidullah or Sultan Kuning 1700-1734) was panicked. The Banjar military forces under the ancient Pangeran Purba and Prince Nata Dilaga can be defeated. In those days, the Dutch and British did not want to interfere in Banjar domestic affairs. In 1714 Banjar with his allies finally retaliated, the son of Prince Purabaya, Gusti Busu was killed, the people of Biaju also ran the depths, left behind the people of Makassar who still survive. Prince Purabaya coalition forces began to experience defeat in the war. He still did not give up but continued to fight until finally Prince Purabaya was killed late 1717.

After the death of Prince Purabaya 1717, very minimal historical record about the Pulau Laut. In several versions of the Dutch Indies, the island of Laut was lent to the VOC to collect swallow nest commodities. This is supported by Dutch source Contract 1797, that: "Pulau Laut Region before becoming the territory of the Dutch East Indies is the kingdom which is the territory of the Sultanate of Banjar. According to the Contract of Agreement in 1797, Pulo Laut or Pulau Laut returned handed over to the Sultanate of Banjar (Sultan Tahmidullah II), because in previous agreements have been lent to the VOC to collect swallow nest commodities. "

Then, what to do with advice? Here comes the second hypothesis about Saranjana. This hypothesis, that the suggestion is "the myth of the region or government of the advanced kingdom" which became the ideals of Prince Purabaya and his son, Gusti Busu. So the Saranjana area is a kind of "collective memory" ie as the "land of dreams" of the first landowner apanage Pulau Laut. Why advice? most likely in the area around the suggestion, the location of the central government of apanage land of Purabaya Prince which was then continued by his son Gusti Busu.
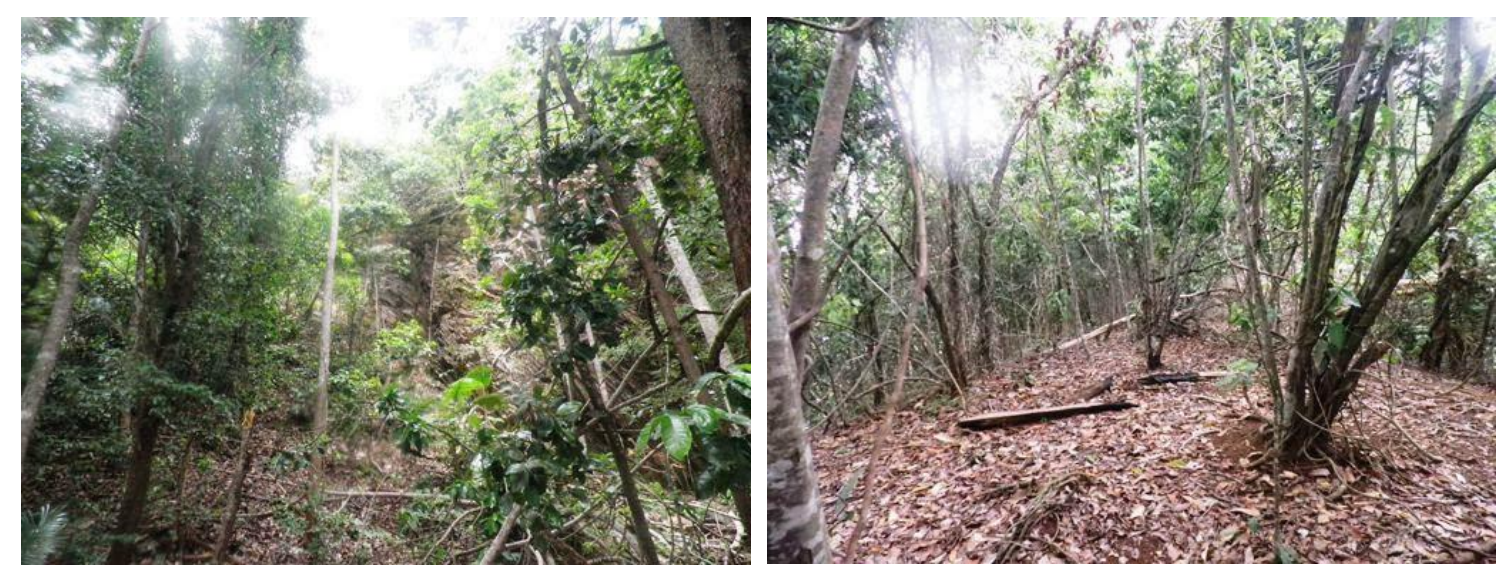

Picture 5. Location Road towards Peak and Peak of Saranjana

This second hypothesis, more inclined to the understanding that the Saranjana is not real. Its position is only as "collective memory". Gradually became the myth of "dream territory" or "fancy country" supporters' community. Therefore, this myth is developed until now. In 
myth, always depicted Saranjana indeed become a developed region.More advanced than the Kingdom of Banjar that there is indeed that era. There is no direct evidence (oral or written), who wrote this connection. Yet this "collective memory" that eventually became mind the fact is what is preserved and maintained today. Naturally, no one can describe in real terms, the side of reality. The reason, because it is from the beginning is a kind of collective memory that developed into a created myth.

Then, why is it on the map of Salomon Muller (1845), the German naturalist in his map entitled "Kaart van de Kust-en Binnenlanden van Banjermasing behoorende tot de Reize in het zuidelijke gedelte van Borneo" (map of coastal and inland Borneo). This map illustrates that there is a Tandjong Serandjana area? Maybe Muller also never to the area in question. Muller only heard it from mouth to mouth, without ever visiting it. In addition, another possibility was in 1845 , when a map was made, a very strong myth about the existence of Saranjana on Pulau Laut.

\section{CONCLUSION}

Then, where is the near-truth conclusion? What is the first hypothesis that the Saranjana is the ethnic state of the Dayak Samihim Tribe? Or the second hypothesis that says that Saranjana (only) dreamland of Prince Purabaya? New data that will answer this. It is not possible, there is a hypothesis or other evidence that can reveal about the next suggestion. In this position, the author is not a judge who convicts historical truth and hypotheses about advice but provides an alternative. Readers who will be more judicious assess, analyze and conclude on their own. Hypotheses are basically only temporary suspicions that are highly likely to change. Hopefully in the future could increase its status into a scientific theory. Closing question, what do you think?

\section{REFERENCES}

Chaudhri, S. D. (1919). Indian Cases. Great Britain: Law Publishing Press.

Fong, G. Y. (1969). Trade and Politics in Banjarmasin 1700-1747. London: Thesis.

Kulke, H. (1986). The Early and the Imperial Kingdom in Southeast Asian history. In D. Marr \& A. Milner (Eds.), Southeast Asia in the 9th to 14th Centuries. Singapore: Institute of Southeast Asian Studies.

Normasunah, N. (2017). Mitos Dalam Legenda Kerajaan Pulau Halimun Di Kabupaten Kotabaru (Myths in Legend of Halimun Island Kingdom in Kotabaru Regency). JURNAL BAHASA, SASTRA DAN PEMBELAJARANNYA, 7(1), 1-8.

Radam, N. H. (2001). Religi Orang Bukit, Suatu Lukisan Struktur dan Fungsi Dalam Kehidupan Sosial-Ekonomi. Yogyakarta: Yayasan Semesta.

Salomon Muller. (1845). Kaart van de Kust-en Binnenlanden van Banjermasing behoorende tot 
de Reize in het zuidelijke gedelte van Borneo.

Schwaner, C. A. L. M. (1851). Historische, geografische en statistieke aanteekeningen betreffende Tanah Boemboe: aangetroffen onder de bij het Gouvernement van Nederlandsch-Indië berustende papieren van van C.A.L.M. Schwaner. Batavia: Tijdschrift voor Indische Taal-, Lan, en Volkenkunde.

The Governor's letter of Macassar to Batavia, 24 November 1717. (n.d.).

Thompson, P. (2012). Suara Dari Masa Silam: Teori dan Metode Sejarah Lisan. Yogyakarta: Penerbit Ombak.

Vansina, J. (2014). Tradisi Lisan sebagai Sejarah. Yogyakarta: Penerbit Ombak.

Veth, P. J. (1869). Aardrijkskundig en statistisch woordenboek van Nederlandsch Indie: bewerkt naar de jongste en beste berigten. Amsterdam: P.N. van Kampen. 